\title{
PENINGKATAN KEPERCAYAAN DIRI SISWA KELAS X MELALUI PELATIHAN ASERTIF DI SMA NEGERI 1 BAGAN SINEMBAH
}

\author{
Tiorensi
}

Surel: tiorensi63@gmail.com

\begin{abstract}
ABSTRAK
Tujuan penelitian ini adalah: Meningkatkan kepercayaan diri siswa kelas X SMA Negeri I Bagan Sinembah Tahun Pelajaran 2016/2017 Melalui Pelatihan Asertif. Prosedur perbaikan pembelajaran meliputi kegiatan pelaksanaan penelitian tindakan kelas yang disusun oleh Kemmis dan Mc Targgat yang terdiri dari 4 tahap yaitu perencanaan tindakan observasi dan refleksi, serta pelaksanaan penelitian ini dirancang 2 siklus, dengan hasil Secara kuantitatif diperoleh hasil siklus I dari sebanyak 37 orang siswa yang di tes skala kepercayaan dirinya terdapat 10 orang yang memiliki kepercayaan diri Rendah, 19 orang memiliki kepercayaan diri Sedang dan hanya 6 orang yang memiliki kepercayaan diri yang Tinggi terjadi peningkatan yang sangat signifikan pada siklus II yaitu dari sebanyak 37 orang siswa yang dilakukan postes skala kepercayaan dirinya terdapat 15 orang memiliki kepercayaan diri Sedang dan hanya 22 orang yang memiliki kepercayaan diri yang Tinggi.
\end{abstract}

Kata Kunci: Kepercayaan Diri, Pelatihan Asertif

\section{Pendahuluan}

Sebagai guru Bimbingan konseling di SMA Negeri I Bagan Sinembah, saya sering melakukan observasi kekelas dan berdiskusi dengan guru yang sedang mengampuh matapelajaran maupun guru walikelas untuk mengetahui tingkat kepercayaan diri siswa, pada observasi yang dilakukan di kelas $\mathrm{X}$ SMA Negeri I Bagan Sinembah diperoleh bahwa: terlihat setengah dari jumlah siswa kurang memiliki rasa percaya diri. Hal ini terlihat ketika guru mata pelajaran menunjuk siswa untuk maju kedepan kelas untuk mengerjakan soal, guru bertanya dan guru meminta menanggapi, banyak siswa yang malu-malu dan cenderung tidak percaya diri ketika sedang berbicara didepan teman-teman kelasnya maupun memberikan tanggapan.
Selain itu juga ketika guru mata pelajaran menanyakan sesuatu kepada siswa, kebanyakan siswa hanya diam dan senyum saja. Idealnya ketika siswa ditunjuk untuk maju kedepan kelas siswa seharusnya langsung kedepan kelas tanpa harus malu-malu, begitupun ketika ditanya seharusnya siswa menjawab tanpa ragu-ragu.

Kondisi ini membuat proses belajar mengajar dikelas tidak berlangsung dengan optimal, solusi pintas yang diambil guru mata pelajaran tersebut harus menunjuk dan terkadang juga harus membujuk terlebih dahulu agar siswa mau maju kedepan kelas. Sebagai guru bimbingan konseling tentu dibuka layanan untuk berdikusi masalah setiap siswa, namun siswa tidak mau menceritakan masalahnya, siswa juga tidak mau menceritakan kepada teman sekelasnya. Keadaan ini sering 

menyulitkan guru bimbingan dan konseling untuk membantu siswa yang terlihat memiliki masalah. Kebanyakan siswa malu dan merasa tidak percaya diri untuk menceritakan masalahnya kepada guru bimbingan dan konseling maupun teman sekelasnya. Dari beberapa penuturan guru mata pelajaran, ditemukan fakta bahwa banyak siswa yang tidak percaya akan kemampuan sendiri sehingga memilih untuk melihat pekerjaan temannya.

Dari hasil observasi diatas menunjukan bahwa kurangnya rasa kepercayaan diri menjadi sebuah masalah yang harus mendapat perhatian di Kelas X SMA Negeri I Bagan Sinembah. Oleh karena itu, salah satu cara untuk meningkatkan kepercayaan diri siswa yaitu dengan diadakan pelatihan asertif. Pelatihan asertif itu sendiri sebenarnya merupakan teknik untuk meningkatkan perilaku asertif, namun apabila dipahami lebih lanjut pelatihan asertif dapat juga digunakan untuk meningkatkan kepercayaan diri siswa. Asumsi dasar dari pelatihan asertifitas adalah bahwa setiap orang mempunyai hak untuk mengungkapkan perasaannya, pendapat, apa yang diyakini serta sikap untuk melakukan suatu hal tanpa ragu tetapi tidak menyakiti perasaan orang lain (Corey, 2003).

\section{METODE PENELITIAN}

Penelitian ini menggunakan pendekatan penelitian tindakan kelas. Suyanto (1996) menyebutkan bahwa penelitian tindakan kelas adalah bentuk penelitian yang bersifat reaktif dengan melakukan tindakan-tindakan tertentu untuk meningkatkan pembelajaran di kelas secara professional. Suharsimi Arikunto (2006) juga menjelaskan bahwa penelitian tindakan adalah penelitian tentang hal-hal yang terjadi di masyarakat atau kelompok sasaran dan hasilnya langsung dapat dikenakan pada masyarakat yang bersangkutan.

Kegiatan pelaksanaan penelitian tindakan kelas yang disusun oleh Kemmis dan Mc Targgat yang terdiri dari 4 tahap yaitu perencanaan tindakan observasi dan refleksi, serta pelaksanaan penelitian ini direncanakan 2 siklus.

\section{HASIL PENELITIAN DAN PEMBAHASAN}

Hasil dari pretes sebelum dilaksanakannya tindakan diperoleh hasil skala kepercayaan diri siswa seperti grafik dibawah ini:

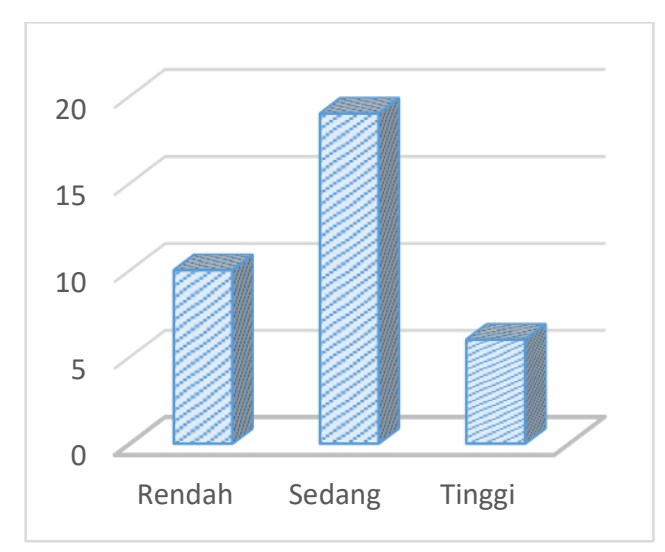

Grafik Skala Kepercayaan Diri

Dari grafik di atas dapat dilihat dari sebanyak 37 orang siswa yang di tes skala kepercayaan dirinya 
terdapat 10 orang yang memiliki kepercayaan diri Rendah, 19 orang memiliki kepercayaan diri Sedang dan hanya 6 orang yang memiliki kepercayaan diri yang Tinggi.

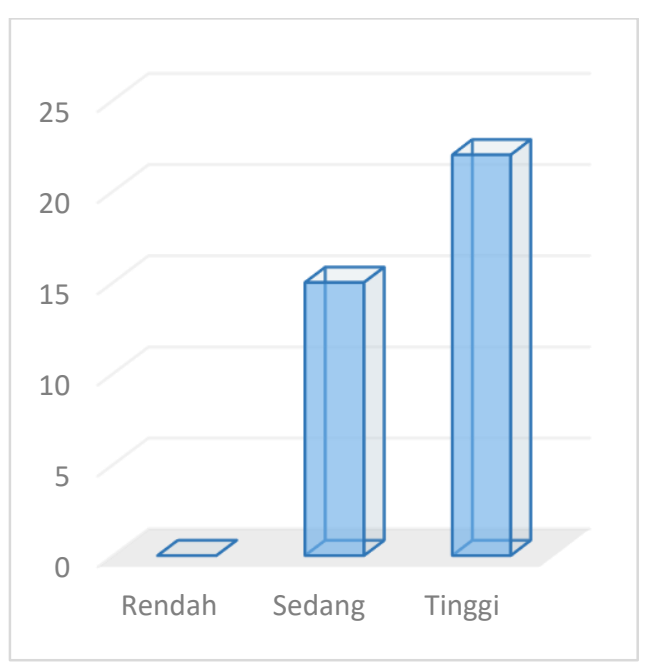

Grafik Skala Kepercayaan Diri

Dari grafik di atas dapat dilihat dari sebanyak 37 orang siswa yang dilakukan postes skala kepercayaan dirinya terdapat 15 orang memiliki kepercayaan diri Sedang dan hanya 22 orang yang memiliki kepercayaan diri yang Tinggi terjadi peningkatan yang sangat signifikan. Peningkatan kepercayaan diri mulai ditunjukkan siswa pada tindakan ke-IV di mana partisipasi aktif dalam kelas mulai terlihat, siswa- siswa tersebut berani menyampaikan contoh perilaku asertif dengan benar dan ada beberapa yang tidak perlu ditunjuk untuk menyampaikan ide-idenya. Hal ini sekaligus menunjukkan adanya peningkatan percaya diri dalam diri siswa tersebut.

\section{Pembahasan}

Pelaksanaan metode pelatihan asertif dalam rangka meningkatkan kepercayaan diri siswa telah dilaksanakan dengan baik dan telah berjalan sesuai dengan tujuan karena hasil skala menunjukan adanya peningkatan. Peningkatan kepercayaan diri pada penelitian ini dilakukan dengan melakukan 2 siklus Penelitian tindakan kelas dengan setiap siklusnya diterapkan 2 kali tindakan dalam empat pertemuan melalui diskusi kelompok, ceramah, role playing, studi kasus dan pengisian lembar kerja siswa. Pembahasan tersebut terdapat dalam Lampiran Satuan layanan Bimbingan dan Konseling tentang metode pelatihan asertif.

Secara kuantitatif diperoleh hasil siklus I dari sebanyak 37 orang siswa yang di tes skala kepercayaan dirinya terdapat 10 orang yang memiliki kepercayaan diri Rendah, 19 orang memiliki kepercayaan diri Sedang dan hanya 6 orang yang memiliki kepercayaan diri yang Tinggi terjadi peningkatan yang sangat signifikan pada siklus II yaitu dari sebanyak 37 orang siswa yang dilakukan postes skala kepercayaan dirinya terdapat 15 orang memiliki kepercayaan diri Sedang dan hanya 22 orang yang memiliki kepercayaan diri yang Tinggi.

Peningkatan skor kepercayaan diri siswa didukung oleh beberapa hal. Secara teknis, kolaborasi yang baik antara peneliti, guru wali kelas dan siswa memberikan pengaruh positif terhadap lancarnya 
pelaksanaan tindakan. Antusiasme siswa yang tinggi dalam mengikuti pelatihan asertif, menjadikan pelatihan berjalan lancar. Materi bimbingan yang disampaikan oleh peneliti membuat siswa memahami tujuan dari tindakan metode pelatihan asertif.

\section{SIMPULAN}

Berdasarkan hasil Penelitian Tindakan Kelas (PTK) dengan judul "Peningkatan Kepercayaan Diri Siswa Kelas X Melalui Pelatihan Asertif di SMA Negeri 1 Bagan Sinembah", dapat ditarik kesimpulan sebagai berikut :

a. Secara kuantitatif diperoleh hasil siklus I dari sebanyak 37 orang siswa yang di tes skala kepercayaan dirinya terdapat 10 orang yang memiliki kepercayaan diri Rendah, 19 orang memiliki kepercayaan diri Sedang dan hanya 6 orang yang memiliki kepercayaan diri yang Tinggi terjadi peningkatan yang sangat signifikan pada siklus II yaitu dari sebanyak 37 orang siswa yang dilakukan postes skala kepercayaan dirinya terdapat 15 orang memiliki kepercayaan diri Sedang dan hanya 22 orang yang memiliki kepercayaan diri yang Tinggi.

b. Berdasarkan pengamatan peneliti melalui observasi pada saat pemberian tindakan, peningkatan kepercayaan diri ditunjang dari siswa yang menunjukkan antusias tinggi dalam metode pelatihan asertif dari kegiatan pertama yang berupa pemberian pengertian mengenai perilaku asertif, kegiatan kedua berupa studi kasus, kegiatan ketiga berupa diskusi dan bermain peran (role playing) dan kegiatan keempat yang berupa pemberian contoh perilaku asertif yang benar (modeling).

\section{DAFTAR RUJUKAN}

Al-Mighwar, M. 2006. Psikologi Remaja. Bandung: Pustaka Setia.

Angelis, Barbara. 2005. Confidence (Percaya Diri). Jakarta: Gramedia Pustaka Utama.

Dery, Iswidharmanjaya. 2004. Satu

Hari Menjadi Lebih Percaya

Diri. Jakarta: Media

Komputindo.

Geldard, Kathryn \& Geldard, David. 2011. Konseling Remaja. Yogyakarta: Pustaka Pelajar.

Hetti, Rahmawati. 2008. Modifikasi Perilaku. Malang: LP3 Universitas Negeri Malang.

Nursalim dkk. 2005. Strategi Konseling. Surabaya: Unesa University Press. Panut

Panuju \& Ida Umami. 2005. Psikologi Remaja. Yogyakarta:

Suharsimi, Arikunto. 2006. Prosedur Penelitian Suatu Pendekatan Praktek. Jakarta: Rineka Cipta.

Wacana, Tiara; Saifudin Azwar. 2009. Penyusunan Skala Psikologi. Yogyakarta: Pustaka Pelajar. 